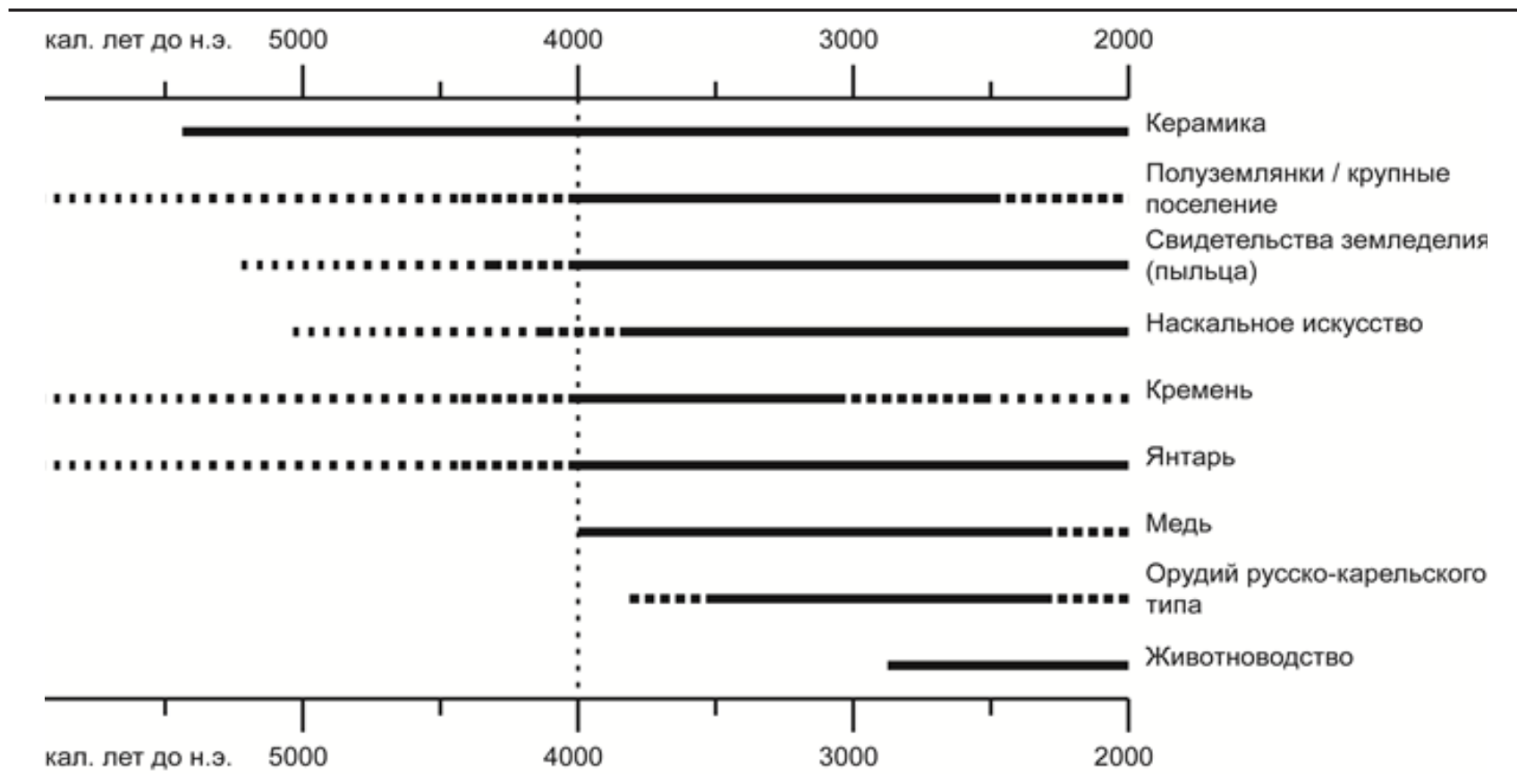

Рис. 2. Упрощённая схема возникновения некоторых неолитических черт и индикаторы неолитизации в северной Европе (взята с исправлениями из Nordqvist, Kriiska, в печати)

(C) 2014

\title{
DURATION OF THE NEOLITHIZATION: A NORTHERN VIEW
}

K. Nordqvist, postgraduate student of Department of Archaeology University of Oulu, Oulu (Finland)

Annotation: This paper discusses the Neolithization and its duration in north-east Europe, traditionally seen as peripheral and not actually Neolithic. It is proposed, through the case studies of pottery, cultivation, settlement and mass production, that conventional, Eurocentric views and definitions of the Neolithic are inadequate - Neolithic and Neolithization are much more diverse and multifaceted phenomena when observed on Eurasian or global scale. Further, Neolithization does not imply simply a technological or economic change but a more pervasive transformation in worldview. Neolithization in north-east Europe was a slow process, which took over two millennia, from the later 6th millennium BC to the mid-3rd millennium BC, or even further. Lastly, contrary to the traditional ideas propagating southern and ultimately Near-eastern origins, Northern Neolithic seems to have deep roots also in the East.

Keywords: Neolithic; Neolithization; north-east Europe; material culture; pottery; cultivation; settlement; mass production.

УДК 902

\section{ПЛАНИГРАФИЧЕСКИЙ АНАЛИЗ МАТЕРИАЛОВ СТОЯНКИ СТАРЫЕ ВОЙКОВИЧИ 1 (ПО ДАННЫМ ТРАСОЛОГИИ)}

(C) 2014

Г.Н.Поплевко, старший научный сотрудник экспериментально-трасологической лаборатории Институт истории материальной культуры РАН, Санкт-Петербург (Россия)

Аннотация. Комплексное исследование кремневых материалов торфяниковой стоянки Старые Войковичи 1 включаеттехнологический, трасологический ипланиграфический анализ кремневых изделий. Для трасологического изучения были отобраны все изделия с ретушью, типологически оформленные орудия, пластины и их фрагменты. Соотношение данных типологического и трасологического анализа показывает, что с помощью трасологии мы можем получить почти в пять раз большее количество орудий и более полную картину хозяйственной деятельности на стоянке. На план раскопа 2004-2005 гг. были нанесены все орудий, выделенные с помощью трасологического анализа. Основное количество орудий сконцентрировано в раскопе 2004 г. в нескольких квадратах, расположенных в виде вытянутого пятна. Это дало возможность предположить, что в этом месте было жилое пространство стоянки. Еще два пятна концентрации орудий можно связать с производственными местами на площади стоянки. Таким образом, можно констатировать, что трасологическое исследование материалов археологический памятников каменного века позволяют уточнить хронологическую принадлежность последних по набору хозяйственного комплекса и определить хозяйственный тип памятника и предположить местонахождение жилого пространства. Стоянка Старые Войковичи 1 может быть определена как сезонный охотничий лагерь финального мезолита и перехода к раннему неолиту.

Ключевые слова. Археология; неолит; комплексное исследование; трасологический анализ; реконструкция хозяйственной деятельности; кремневая индустрия. 
Торфяниковая стоянка Старые Войковичи 1 была открыта В.К. Поликарповым. Первые археологические исследования ее были проведены М.М. Чернявским в 1988 г. [11, с. 91-99]. Дальнейшее исследование стоянки было продолжено А.А. Разлуцкой в 2004 г. [10, с. 258-260; 8] и в 2005 г. [9]. Материалы исследования А.А. Разлуцкой были преданы для проведения комплексного: технологического, трасологического и планиграфического анализа. В результате полевых работ 2004-2005 гг. было получено большое количество (более 5 тыс. единиц) материалов из кремня и фрагментов керамики. По данным А.А. Разлуцкой, в качестве сырья широко использовался местный кремень высокого качества разных оттенков синеватосерого цвета. Для изучения были отобраны все изделия c ретушью, типологически оформленные орудия, пластины и их фрагменты. Комплексное исследование кремневых материалов торфяниковой стоянки Старые Войковичи 1 проводится уже несколько лет и, частично, результаты ее изучения уже опубликованы [6; 7]. Работа была начата при поддержке РГНФ, проект № 10-01$00553 a /$ м.

В данной работе будет сделан акцент на планиграфический анализ орудий, выделенных с помощью трасологического метода исследования кремневых изделий и показано распределение этих орудий на площади стоянки Старые Войковичии 1. Вначале были исследованы типологически выраженные орудия, среди которых были выявлены изделия с микроследами использования их в разных хозяйственных операциях, а на втором этапе - были изучены пластинчатые сколы и их фрагменты. Отдельно изучалась большая выборка технологических отходов разных размеров с целью выявления микроследов возможного их употребления в качестве орудий. Анализ сколов показал, что отщепы и их фрагменты, не имеющие вторичной обработки, использовались в качестве заготовок для орудий крайне редко. В основном использовали пластины и их фрагменты, реже пластинчатые отщепы.

* Выражаю глубокую признательность автору раскопок 2004-2005 гг. стоянки Старые Войковичи 1 А.А Разлуцкой, за предоставленную возможность работы с материалами

Технологический анализ кремневых изделий торфяниковой стоянки Старые Войковичи 1 показал, что

расщепление кремня вели с помощью каменных отбойников. Основное количество многотысячной коллекции отщепов было получено с их помощью. Расщепление пластин проводилось с использованием ручного отжима и удара через роговой посредник. Все изделия имеющие ретушь и правильные сколы с морфологией близкой типологическим формам орудий с ретушью были отобраны для трасологического исследования под микроскопом. Вся выборка изделий была изучена с помощью стереоскопического микроскопа MC-2CR-ZOOM и металлографического микроскопа ЛабоМет-И-2 с увеличением от 10 до 500 раз. Из типологически выраженных изделий было исследовано - 5 наконечников стрел, 58 экз. - составляют скребки, скобели и отщепы с ретушью, 7 нуклеусов и 3 скола-подправки поверхности скалывания нуклеусов. Все остальные изделия - фрагменты пластин. Всего было исследовано более 600 экз. Отщепы не имеющие микроследов были исключены из дальнейшей обработки, поэтому в данном исследовании будет рассматриваться коллекция из 496 изделий. Из них для трасологического исследования были отобраны все отщепы с ретушью - 87 экз. и морфологически выраженные 7 нуклеусов в коллекции (рис. 1), а также 397 экз. пластин и их фрагментов. Из них 47 экз. небольших фрагментов пластин ещё предстоит исследовать трасологически Данная коллекция включает, помимо целых пластин и их фрагментов, 5 наконечников стрел и их фрагменты. Из 87 экз. отщепов можно типологически выделить полтора десятка морфологически выраженных скребков, 6 экз. крупных и 15 экз. пластинчатых, а остальные - средние и часть мелких отщепов с ретушью. В основной массе все изделия, за исключением нескольких пластин и большей части скребков, не имеют вторичной обработки. На первый взгляд можно предположить, что это была мастерская по изготовлению пластин и отщепов для последующей их транспортировки или обмена. Однако трасологическое исследование всей выборки изделий показало, что это не совсем так. Почти три четверти исследованных изделий имели ярко выраженные микроследы использования их в различных операциях, хотя морфологически не имели намеренной ретуши или ретуши утилизации.

Раскоп 2004 г. был общей площадью в 36 м кв. А.А. Разлуцкая приводит подробную характеристику коллекции кремневых изделий из раскопок 2004 г., насчитывающую 1784 экз. [9, с. 258-260]. Данные о раскопках в 2005 г. пока не опубликованы. Для торфяниковой стоянки Старые Войковичи 1 в целом характерна отщеповая техника расщепления кремня, так как основное количество изделий составляют отщепы разной морфологии и их фрагменты. Если вся коллекция 2004-2005 гг. насчитывает около 5 тыс. экз., то пластины и их фрагменты составляют всего - 397 экз. (это примерно $8 \%$ от общего количества сколов всей коллекции). Технологический анализ пластин и их фрагментов предполагает изучение метрических параметров $[1 ; 2 ; 3]$. В частности, у части пластин и фрагментов (328 экз.) были измерены показатели длины, результаты замеров опубликованы $[4 ; 6 ; 7]$. Абсолютное большинство среди пластин данной коллекции составляют пластины во фрагментах. По длине фрагменты пластин распределяются на три группы:

Первая группа: объединяет -174 экз. пластин и фрагментов длиной от 2,0 см до 3,0 см. Вторая группа: насчитывает - 92 экз. пластин и фрагментов длиной от 3,5 см до 5,0 см. Третья группа: составляет - 49 экз. фрагменты пластин длиной 1,0 - 1,5 cм.

Основную часть коллекции представляют фрагменты небольших размеров, что может косвенно свидетельствовать об использовании их в виде вкладышей в рукоятях. Сами рукояти могли быть как деревянными, так и роговыми или костяными. Для узких пластин использовали роговые и костяные заготовки для оправ, а для более широких пластин было возможно использование рукоятей из дерева, т.к. эти фрагменты требуют более глубокого погружения в оправу.

Трасологическому исследованию была подвергнута выборка, включающая 449 экз. После трасологического анализа было выделено большее количество рабочих лезвий орудий, т.к. на некоторых изделиях было по 2 рабочих лезвия, также были встречены полифункциональные орудия с двумя и более рабочими лезвиями. Поэтому общее количество орудий стало больше, чем фактических заготовок, т.к. были учтены все рабочие лезвия. Так из 449 экз. у 125 экз. не было микропризнаков, они без следов использования, следовательно, на оставшихся 324 экз. было зафиксировано 415 рабочих лезвий. Ниже показано распределение выявленных орудий по различным категориям в целом (таблица 1).

Соотношение данных, полученных при типологическом и трасологическом анализе, показывает, что во всей коллекции морфологически было выделено 83 экз. разных орудий, а после трасологического анализа их количество возросло до 413 рабочих лезвий орудий разных функций (таблица 1). Это наиболее наглядный пример необходимости творческого сотрудничества археологов-практиков и археологов-трасологов, т.к. именно такое взаимодействие и позволяет получить максимум информации для проведения хозяйственной Самарский научный вестник. 2014. № 3(8) 
реконструкции на изучаемом памятнике.

Значимость проведения трасологического исследования каменных орудий очевидна не только из-за большого количества выделяемых орудий, но и потому что оно позволяет выделять новые орудия и определять обрабатываемый ими материал. Так на таблице 2 показано как распределяются на плане стоянки сверла для обработки кости (рога), дерева, камня и проколки. Основное количество изделий этой категории обнаружено в раскопе 2004 г. кв. 79-82 на плане стоянки продолжают линию квадратов 74-78. Для удобства формирования таблиц они в таблицах расположены ниже кв. 74-78. В кв. 61 и 88 обнаружено сразу соответственно 4 и 3 экз. Основное количество этих орудий использовались для обработки кости, рога. В раскопе 2005 г. также, для удобства, были смещены кв. 109-112 и расположены внизу. На плане они должны были располагаться по линии кв. 104-110-111 и кв. 108-109-112. В таблице 3 приводится распределение орудий для обработки мяса, рыбы на площади раскопов. Здесь также отмечается концентрация орудий на площади раскопа 2004 г. Наибольшее количество орудий отмечено в кв. $80-12$ экз., в кв. $86-10$ экз. Скопление из 5 - 7 экз. отмечено в кв. 53, 58, 59, 61$62,65,72,78$. Еще в 16-ти квадратах встречено 3-4 экз. Можно сделать предположение, что скопление в одном квадрате нескольких вкладышей ножа или гарпуна свидетельствует о том, что на этом месте было оставлено орудие с кремневыми вкладышами. На таблице 4 представлено распределение скребков на площади стоянки. Скребков найдено небольшое количество, они в основном были использованы для обработки кости, рога и значительно реже для дерева. Для обработки шкур было использовано только два скребка (рис. 1). В кв. 83 обнаружено 3 экз., в остальных случаях по 1-2 экз. В таблице 5 приведены данные по нескольким категориям орудий. Наибольшее число составляют скобели. В 9-ти кв. их обнаружено по 3 экз. В кв. 80 отмечено 6 экз., в кв. $90-5$ экз. В 4-х кв. обнаружено по 3 экз. строгальных ножей, а в кв. $90-4$ экз. Другие категории присутствуют в меньшем количестве. Наибольшая концентрация орудий отмечена в кв. 80 и 90. В 6 кв. встречается от 5-7 экз., а в 17-ти кв. по 3-4 экз. орудий. В таблице 6 представлены все орудия, использованные для переработки продуктов охоты и рыболовства. Помимо ножей и вкладышей гарпуна сюда включены проколки и скребки, их немного, поэтому увеличения концентраций орудий в квадратах несущественно. Это кв. 48, 53, 59, 62, 90. На таблице 7 показано распределение орудий по обработке дерева и камня. Доминируют вкладыши строгальных ножей и скобели. В 7-ми кв. отмечено по 3-4 орудия. Ярких концентраций не выявлено. Основное количество орудий находится в раскопе 2004 г. Орудия для работ по камню единичны: ретушеры, сверло и скобель по мягкому камню или ракушке. В таблице 8 приводятся данные по распределению орудий для обработки кости, рога. Здесь можно отметить концентрацию из 9-11 экз. в кв. 61, 80 и 90. В кв. 54 найдено 7 экз. Еще в 12-ти кв. встречается по 4-5 экз. орудий. Наибольшее количество орудий в раскопе 2004 г. по его центральной линии квадратов. В таблице 9 показано, как распространены выделенные орудия по площади раскопов. Раскоп 2004 г. очень насыщен орудиями, особенно в центральной его части и в кв. $80-24$ экз. В нем сконцентрированы скобели для обработки кости, рога, несколько вкладышей ножа для мяса и вкладышей гарпуна. Концентрация орудий также отмечается в кв. 61- 20 экз., в кв. $90-17$ экз., в кв. 53 - 15 эКз., в кв. 88 - 14 эКз., в кв. 54. 62, 86 - по 12 экз., в кв. 79 - 10 экз., в кв. 59-60, 65 - по 9 экз., в кв. 71-72, 76, 78 - по 8 экз. Можно с уверенностью предполагать, что в этих квадратах на площади стоянки находились производственные места. По аналогии планиграфического анализа материалов других Самарский научный вестник. 2014. № 3(8) памятников пока предварительно можно высказать гипотезу, о том, что в местах скоплений орудий по соседним квадратам были не только производственные места для разной хозяйственной деятельности, но и, возможно, по распределению орудий можно судить и о местонахождении жилой площадки на стоянке в древности. В раскопе 2004 г. можно отметить вытянутую концентрацию орудий в верхней части раскопа (на плане) и меньшее скопление в нижней его части.

Также небольшое скопление орудий в квадратах 2005 г. Жилая площадка ассоциируется с большим скоплением орудий в квадратах раскопа 2004 г., а два других скопления можно связать с производственными площадками на площади стоянки. Поскольку линия кв. 79-82 на плане стоянки продолжает линию кв. 74-78, то скопление в кв. 80 будет находиться в стороне от основного большого скопления орудий. В таблице 10 показано как распределяются изделия без следов использования, которые были трасологически изучены. Здесь мы наблюдаем небольшое скопление в кв. $66,58,67,73$. Концентрация изделий без следов также плотно ложится на большое скопление орудий, с которым может быть связана жилая площадка на стоянке. Таким образом, можно сделать вывод, о том, что только комплексный анализ материалов стоянки Старые Войковичи 1 позволил зафиксировать большой набор орудий, распределить его по видам обрабатываемого сырья и по всей площади раскопов. Планиграфический анализ распределения орудий по квадратам раскопа показал, что на стоянке фиксируется обширное вытянутое пятно, на нем сконцентрировано большая часть находок и которое предварительно может быть определено как жилое пространство. Два других скопления можно связать с производственными площадками, расположенными на стоянке. Несколько квадратов практически не имеют орудий или они присутствуют в 1-2 экз.

Таблица 1 - Соотношение данных типологического и трасологического анализа

\begin{tabular}{|c|c|c|}
\hline Категории орудий & $\begin{array}{c}\text { Данные типологического } \\
\text { анализа }\end{array}$ & $\begin{array}{c}\text { Данные трасологического } \\
\text { анализа }\end{array}$ \\
\hline наконечники & 6 & 5 \\
\hline рубящие & 3 & \\
\hline миниатюрный топорик & 1 & \\
\hline тесла и тесловидные нзделия & 9 & \\
\hline резцы & 14 & 2 \\
\hline скребки & 12 & 64 \\
\hline сколы & 2 & \\
\hline ланцеты & 3 & \\
\hline проколки & 13 & 5 \\
\hline провертки & 1 & \\
\hline скобели & 7 & 94 \\
\hline вкладыши & 12 & \\
\hline ножн для мяса & & 126 \\
\hline вкладыши гарпуна & & 27 \\
\hline сверла & & 27 \\
\hline вкладыши строгальные ножа & & 35 \\
\hline резчнки & & 15 \\
\hline долото & & 10 \\
\hline pетушер & & 3 \\
\hline Итого: & 83 & 413 \\
\hline
\end{tabular}


Таблица 2 - Торфяниковая стоянка Старые Войковичи 1. Распределение трасологически выделенных орудий (сверл и проколок) на плане раскопов 20042005 гг.

\begin{tabular}{|c|c|c|c|c|}
\hline 44 & ${ }^{45} \Delta$ & 46 & ${ }^{47} \Delta$ & ${ }^{48} \Delta$ \\
\hline 49 & 50 & 51 & 52 & ${ }^{53} \Delta \Delta$ \\
\hline${ }^{54} \Delta \boldsymbol{\Delta}$ & $55 \boldsymbol{A}$ & ${ }^{56} \Delta$ & $57 \Delta$ & ${ }^{58} \Delta$ \\
\hline${ }^{59} \Delta$ & 60 & ${ }^{61} \Delta \boldsymbol{\Delta} \boldsymbol{\Delta} \mathbf{\Delta}$ & 62 & 63 \\
\hline 64 & $65 \Delta$ & ${ }^{66} \Delta$ & $67 \Delta$ & 68 \\
\hline 69 & 70 & ${ }^{71} \Delta$ & 72 & 73 \\
\hline 74 & 75 & 76 & 77 & 78 \\
\hline & 79 & ${ }^{80} \boldsymbol{\Lambda}$ & ${ }^{81} \Delta$ & 82 \\
\hline \multicolumn{5}{|c|}{ Раскоп $2005 \mathrm{r}$. } \\
\hline 83 & 84 & 85 & 86 & 87 \\
\hline${ }^{88} \Delta \Delta \boldsymbol{\Lambda}$ & 89 & ${ }^{90} \Delta \Delta$ & 91 & 107 \\
\hline 92 & 93 & 94 & ${ }^{95} \Delta$ & 106 \\
\hline 96 & 97 & 98 & \begin{tabular}{|l|}
99 \\
\end{tabular} & 105 \\
\hline \multirow[t]{4}{*}{100} & ${ }^{101} \Delta$ & 102 & 103 & ${ }^{104} \Delta \mathbf{\Delta} \triangle$ \\
\hline & & & & 108 \\
\hline & & & 1110 & 111 \\
\hline & & & 109 & 112 \\
\hline
\end{tabular}

Условные обозначения: 1 - $\Delta$ - кость, рог; 2 - $\boldsymbol{\Delta}$ - дерево; 3 - $\Delta$-мясо, шкура; 4 - $\Delta$ - камень

Таблица 3 - Торфяниковая стоянка Старые Войковичи 1. Распределение трасологически выделенных орудий (ножей и вкладышей гарпунов) на плане

Pacкon $2004 \mathrm{r}$.

\begin{tabular}{|c|c|c|c|c|}
\hline 44 & ${ }^{45} \Delta$ & ${ }^{46} \Delta$ & ${ }^{47} \Delta$ & ${ }^{48} \Delta$ \\
\hline 49 & ${ }^{50} \Delta \Delta \Delta$ & ${ }^{51} \Delta$ & $\begin{array}{r}{ }^{52} \Delta \Delta \Delta \\
\square\end{array}$ & $\begin{array}{r}\Delta \Delta \Delta \Delta \\
\square \square\end{array}$ \\
\hline${ }^{54} \Delta \Delta_{\square}$ & ${ }^{55 \Delta \Delta}{ }^{55}$ & ${ }^{56} \Delta \Delta$ & ${ }^{57} \Delta \Delta$ & $\Delta \Delta \Delta \Delta \Delta$ \\
\hline $\begin{array}{c}{ }^{59} \Delta \Delta \Delta \\
\square\end{array}$ & ${ }^{60} \Delta \Delta \Delta$ & ${ }^{{ }^{61}} \frac{\Delta \Delta \Delta \Delta}{\Delta \Delta \Delta}$ & ${ }^{62} \Delta \Delta \Delta \Delta \Delta$ & ${ }^{63} \Delta$ \\
\hline 64 & $\begin{array}{c}{ }^{65} \Delta \Delta \Delta \Delta \\
\Delta \quad \square\end{array}$ & ${ }^{66} \Delta \Delta$ & ${ }^{67} \Delta$ & 68 \\
\hline${ }^{69} \Delta$ & ${ }^{70} \Delta$ & ${ }^{71} \Delta \Delta \Delta$ & ${ }^{72} \overrightarrow{\Delta \Delta \Delta}$ & 73 \\
\hline 74 & 75 & ${ }^{{ }^{76} \Delta \Delta_{\square \square}}$ & ${ }^{77} \Delta \Delta \Delta$ & ${ }^{78} \stackrel{\Delta \Delta \Delta \Delta}{\Delta \quad \square}$ \\
\hline & ${ }^{79 \Delta \Delta \Delta}$ & $\begin{array}{l}{ }^{80} \stackrel{\Delta \Delta \Delta \Delta}{\Delta \Delta \Delta} \\
\square \square D \square\end{array}$ & 81 & ${ }^{82} \Delta \Delta$ \\
\hline \multicolumn{5}{|c|}{ Packon 2005 r. } \\
\hline 83 & 84 & 85 & ${ }^{86} \frac{\Delta N \Delta}{\Delta \Delta}[$ & 87 \\
\hline $88 \Delta \Delta \Delta \Delta$ & $89 \Delta$ & ${ }^{90} \Delta \Delta \Delta \Delta$ & ${ }_{91} \Delta \Delta \Delta$ & 107 \\
\hline${ }^{92} \Delta$ & ${ }^{93} \Delta$ & ${ }^{94} \Delta \Delta \Delta$ & ${ }^{95} \Delta$ & 106 \\
\hline$\square$ & ${ }^{97} \Delta \Delta$ & 98 & 99 & 105 \\
\hline${ }^{100} \Delta \Delta$ & ${ }^{101} \Delta$ & 102 & $\begin{array}{r}{ }^{103} \Delta \Delta \\
\end{array}$ & 104 \\
\hline & & & & 108 \\
\hline & & & ${ }^{110} \Delta \Delta \Delta$ & 111 \\
\hline & & & 109 & 112 \\
\hline
\end{tabular}

Устовные обозначения: $\boldsymbol{\Delta}$ - ножи и вктадыши ножей для мяса: $\boldsymbol{D}$ - вктадыши гарпуна длярыбы
Таблица 4 - Торфяниковая стоянка Старые Войковичи 1. Распределение трасологически выделенных орудий (скребков) на плане раскопов 2004-2005 гг.

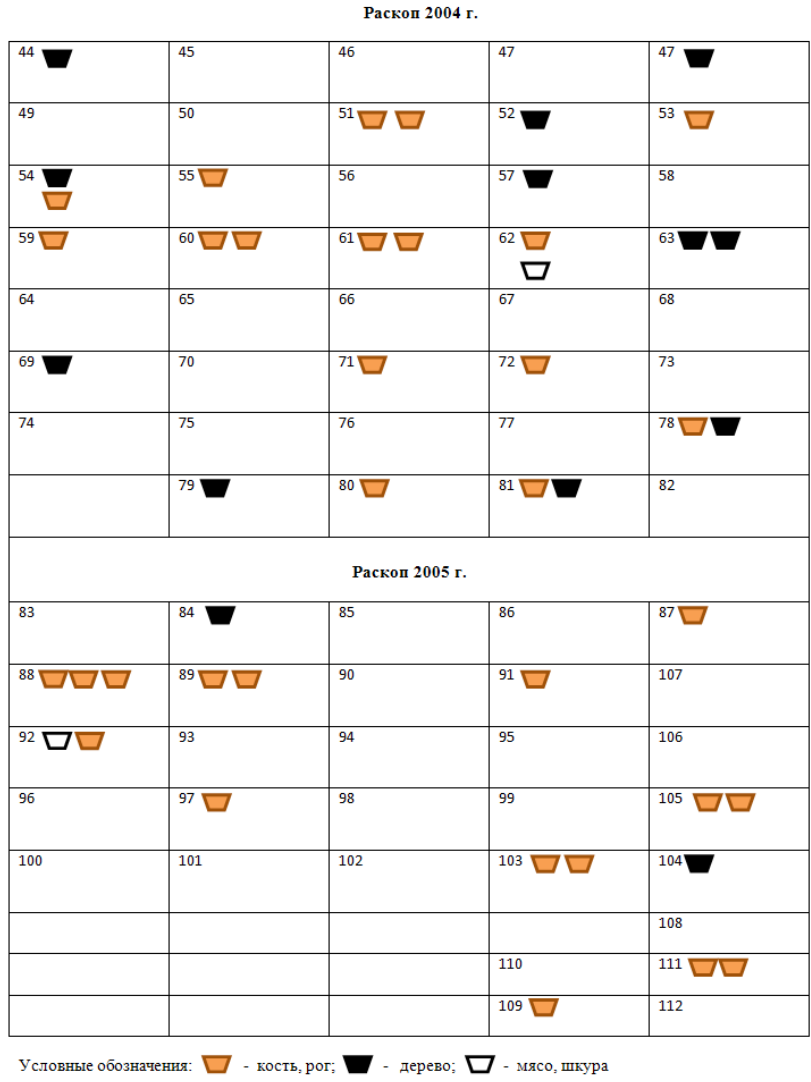

Таблица 5 - Торфяниковая стоянка Старые Войковичи 1. Распределение трасологически выделенных орудий (строгальных ножей, скобелей, резчиков, долот, ретушеров) на плане раскопов 2004-2005

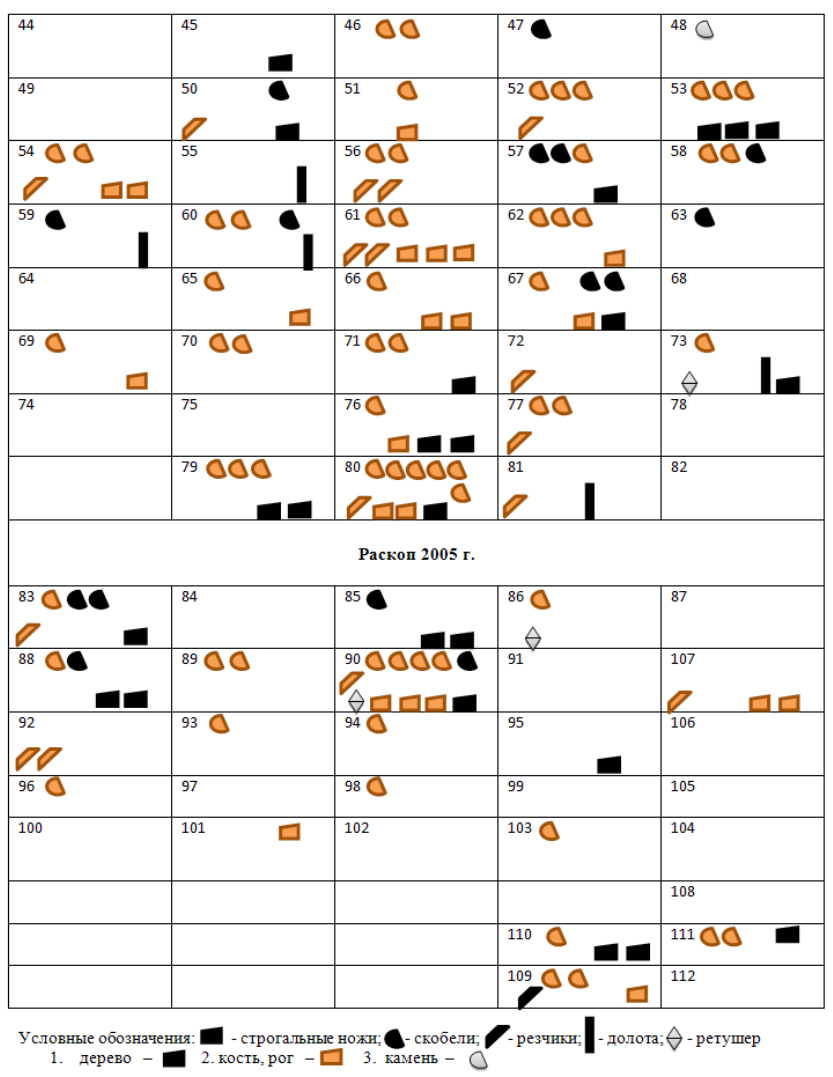


Таблица 6 - Торфяниковая стоянка Старые Войковичи 1. Распределение трасологически выделенных орудий для обработки рыбы, мяса и шкур животных на плане раскопов 2004-2005 гг.

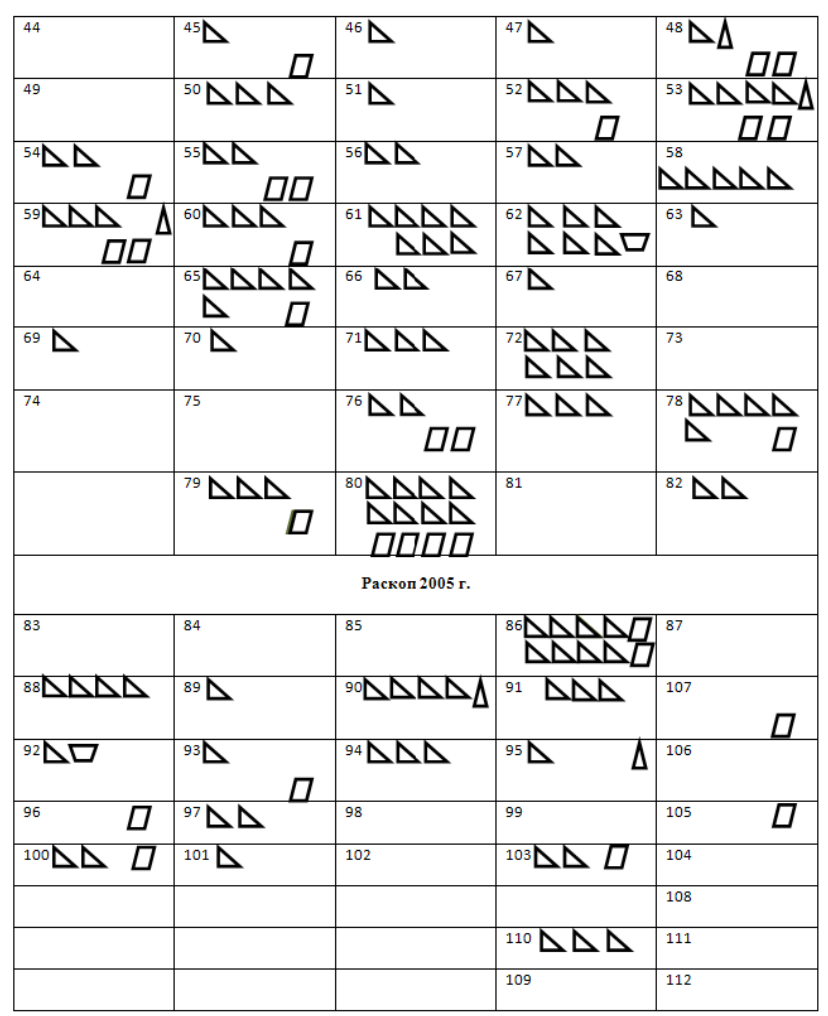

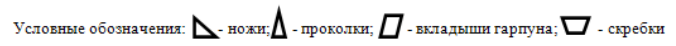

Таблица 7 - Торфяниковая стоянка Старые Войковичи 1. Распределение трасологически выделенных орудий для обработки дерева и камня на плане раскопов 2004-2005 гг.

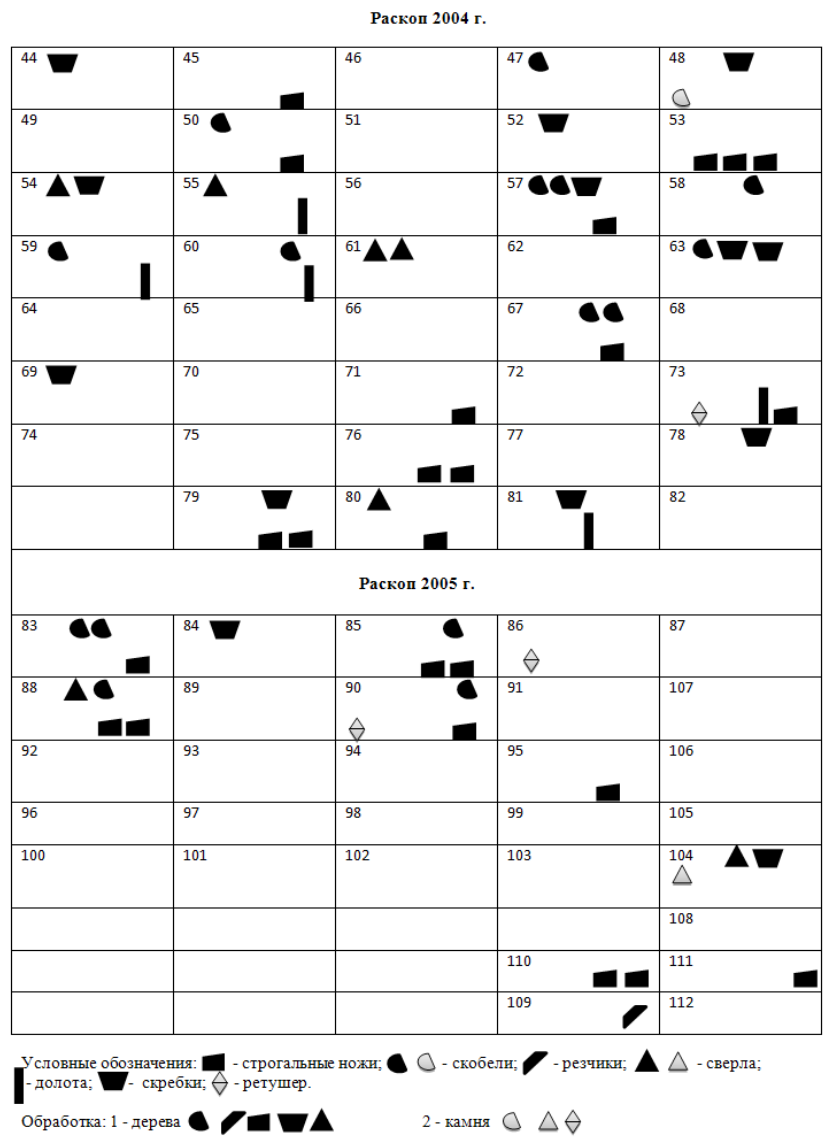

Таблица 8 - Торфяниковая стоянка Старые Войковичи 1. Распределение трасологически выделенных орудий для обработки кости, рога на плане раскопов 2004-2005 гг.

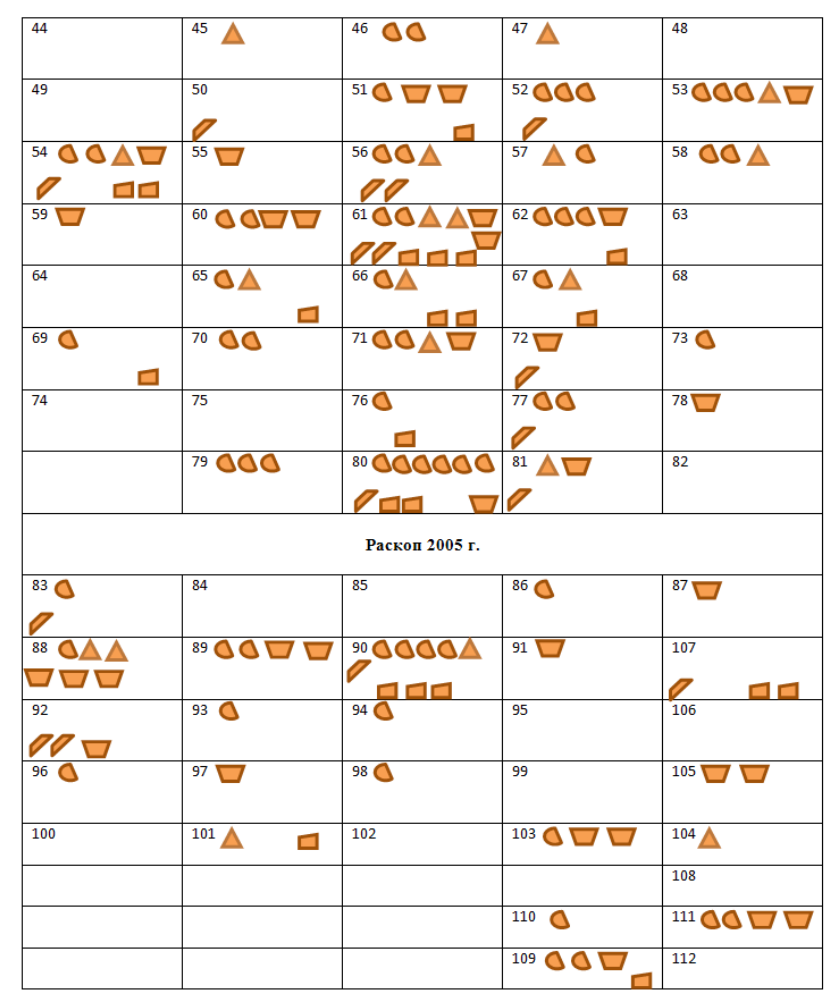

Условные обозначения: $\square$ - строгальные ножн; $Q$ - скобели; $\square$-резчики; $\Delta$-сверла; $\square$ - скребки

Таблица 9 - Торфяниковая стоянка Старые Войковичи 1. Распределение всех трасологически выделенных орудий на плане раскопов 2004-2005 гг.

Packon 2004 r.

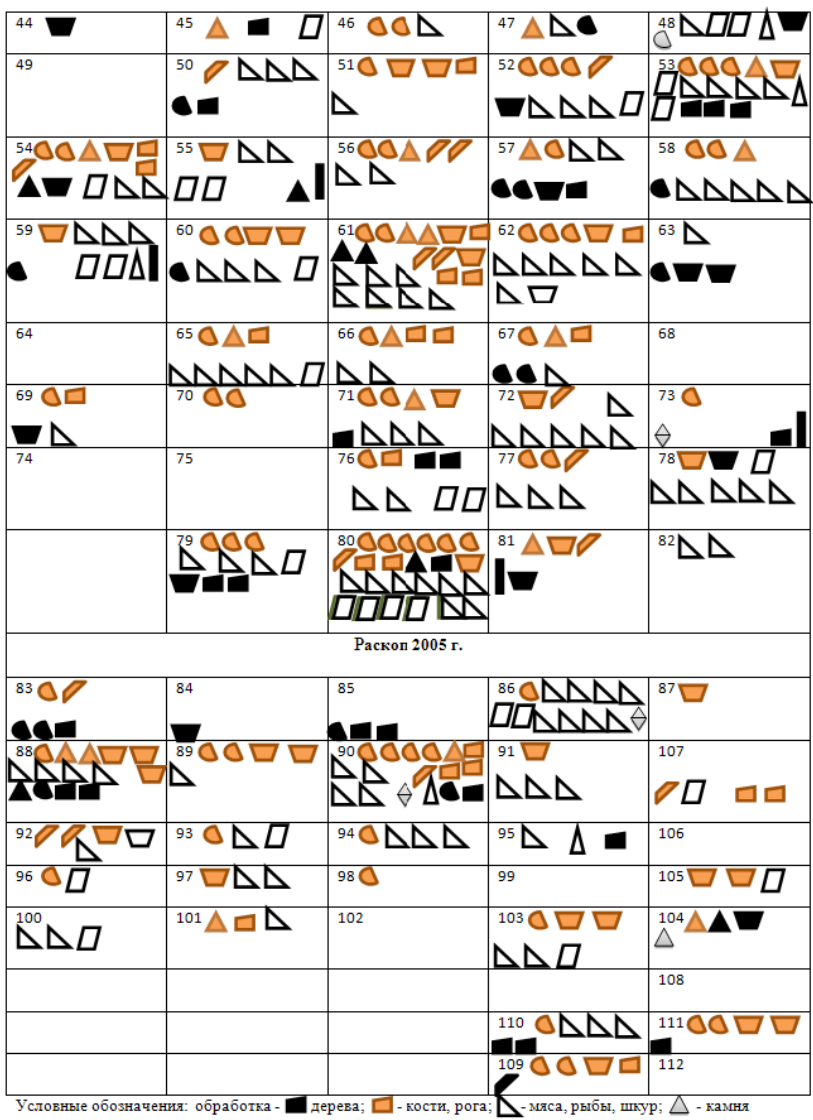


Таблица 10 - Торфяниковая стоянка Старые Войковичи 1. Распределение кремневых изделий без следов использования на плане раскопов 2004-2005 гг. (только из изученной выборки)

\begin{tabular}{|c|c|c|c|c|}
\hline 44 & ${ }^{45} 000$ & 46 & 47 & ${ }^{48} 00$ \\
\hline${ }^{49} 000$ & ${ }^{50} \mathrm{O}$ & ${ }^{51} 00$ & ${ }^{52} 000$ & ${ }^{53} 00000$ \\
\hline${ }^{54} 00$ & ${ }^{55} 00$ & ${ }^{56} 0$ & ${ }^{57} 00$ & ${ }^{58} 00000$ \\
\hline${ }^{59} 0000$ & ${ }^{60} 000$ & ${ }^{61} 00$ & ${ }^{62} 00$ & ${ }^{63} \mathrm{O}$ \\
\hline${ }^{64} 00$ & ${ }^{65} 00$ & ${ }^{66} 00000000$ & ${ }^{67} 00000$ & ${ }^{68} 0$ \\
\hline 69 & 70 & ${ }^{71} 00000$ & ${ }^{72} 000$ & ${ }^{73} 0$ \\
\hline 74 & 75 & ${ }^{76} 00$ & ${ }^{77} 000$ & 78 \\
\hline & ${ }^{79} 0000$ & ${ }^{80} 0000$ & ${ }^{81} 00$ & ${ }^{82} 0$ \\
\hline \multicolumn{5}{|c|}{ Раскоп 2005 r. } \\
\hline${ }^{83} 0$ & 84 & ${ }^{85} 0$ & ${ }^{86} 0$ & ${ }^{87} 0$ \\
\hline${ }^{88} 00$ & ${ }^{89} 00$ & ${ }^{90} 0000$ & ${ }^{91} 0$ & ${ }^{107} 00$ \\
\hline${ }^{92} 0$ & ${ }^{93} 00$ & ${ }^{94} \mathrm{O}$ & ${ }^{95} 0$ & ${ }^{106} \mathrm{O}$ \\
\hline${ }^{96} 0$ & 97 & ${ }^{98} 00$ & 99 & 105 \\
\hline \multirow[t]{4}{*}{100} & ${ }^{101} 000$ & 102 & 103 & ${ }^{104} \mathrm{O}$ \\
\hline & & & & ${ }^{108} 00$ \\
\hline & & & 110 & 111 \\
\hline & & & ${ }^{109} 000$ & ${ }^{112} 0$ \\
\hline
\end{tabular}

Условные обозначения: $\quad$ хремневые нзделия без следов использования

Все трасологически выделенные орудия были объединены в хозяйственные комплексы по обрабатываемым материалам. Так наибольшее количество орудий имеет хозяйственный комплекс орудий по обработке по обработке кости, рога-43,1\%. На втором месте находится хозяйственный комплекс по переработке продуктов охоты $40,4 \%$, далее - по обработке дерева - $15 \%$ и комплекс орудий по обработке камня - $1,5 \%$ (таблица $11 ; 12$ ).

По итогам трасологического исследования стало возможным реконструировать весь хозяйственный комплекс стоянки Старые Войковичи 1 и установить использованный на поселении набор кремневых орудий Количественно преобладают комплексы орудий по отработке кости, рога и по обработке продуктов охоты, что характерно для мезолитических памятников [5;6; 7]. Ещё большее преобладание комплекса орудий по обработке кости, рога было прослежено на материалах мезолитических стоянок Южный Олений остров 1 Южный олений остров $2[5 ; 6 ; 7]$. Там разрыв между комплексами по обработке кости, рога и обработке мяса, шкур составляет более $40 \%$ на каждой стоянке. На стоянке Старые Войковичи 1 разрыв между показателями этих комплексов менее значителен, но также характерен для мезолитических комплексов. В пользу этой хронологической позиции стоянки свидетельствуют и находки 8 микролитов. Они включают 1 экз. острия янисловицкого типа и 2 обломка верхних концов аналогичных орудий. Ещё обнаружен 1 целый и 2 частично обломанных сегмента. Также найден 1 экз. обломанной верхушки микропластинки с ретушью на одном слабо скошенном крае. Отдельно хочется отметить микропластинку со слабым скруглением одного края ретушью на обоих концах. Присутствие микролитов в коллекции также свидетельствует о древнем возрасте стоянки. Они как раз и маркируют ранний возраст стоянки, помимо хозяйственного комплекса. Таким образом, можно констатировать, что трасологическое исследование материалов археологический памятников каменного века 160 позволяют уточнить хронологическую принадлежность последних по набору хозяйственного комплекса и определить хозяйственный тип памятника и предположить местонахождение жилого пространства. Стоянка Старые Войковичи 1 может быть определена как сезонный охотничий лагерь финального мезолита и перехода к раннему неолиту.

Таблица 11 - Распределение трасологически выделенных орудий по хозяйственным комплексам торфяниковой стоянки Старые Войковичи 1

\begin{tabular}{|c|c|c|c|c|c|}
\hline п./п. & $\begin{array}{l}\text { трасологически } \\
\text { выделенные орудня }\end{array}$ & $\begin{array}{l}\text { обработка } \\
\text { продуктов } \\
\text { охоты }\end{array}$ & $\begin{array}{l}\text { обработка } \\
\text { костн, рога }\end{array}$ & $\begin{array}{l}\text { обработка } \\
\text { дерева }\end{array}$ & $\begin{array}{l}\text { обработка } \\
\text { камня }\end{array}$ \\
\hline 1. & наконечники стрел & 5 & & & \\
\hline 2. & ножи для мяса & 126 & & & \\
\hline 3. & вкладыши гарпуна & 27 & & & \\
\hline 4. & проколки & 5 & & & \\
\hline 5. & скребки & 4 & 43 & 17 & \\
\hline 6. & скобели & & 77 & 15 & 2 \\
\hline 7. & сверла & & 20 & 6 & 1 \\
\hline 8. & $\begin{array}{l}\text { вкладыши строгальнога } \\
\text { ножа }\end{array}$ & & 22 & 13 & \\
\hline 9. & резчики & & 13 & 2 & \\
\hline 10. & резцы & & 2 & & \\
\hline 11. & долота & & 1 & 9 & \\
\hline \multirow[t]{3}{*}{12.} & ретушеры & & & & 3 \\
\hline & Итого: & 167 & 178 & 62 & 6 \\
\hline & $\%$ & $40,4 \%$ & $43,1 \%$ & $15 \%$ & $1,5 \%$ \\
\hline
\end{tabular}

Таблица 12 - Гистограмма распределения орудий по хозяйственным комплексам в \%

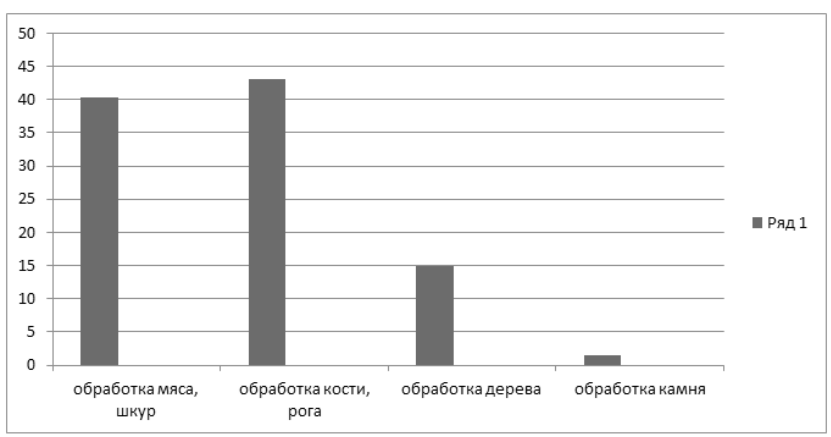

\section{СПИСОК ЛИТЕРАТУРЫ}

1. Поплевко Г.Н. Методический аспект комплексного исследования пластинчатых индустрий (на материалах поселения Кременная III) // Археологические записки, вып. 3 «Каменный век». Ростов-на-Дону, 2003а. С. 143-162.

2. Поплевко Г. Н. К методике определения технических приемов ударных техник скола каменных индустрий (на материалах мезолитической стоянки Вышегора I) // Контактные зоны Евразии на рубеже эпох: Тезисы докл. Самара, 20036. С. $73-80$.

3. Поплевко Г.Н. Критерии определения техники скола каменных индустрий // Международное (XVI Уральское) археологическое совещание. Пермь, 2003в. С. 53-55.

4. Поплевко Г.Н. Методика комплексного исследования каменных индустрий // Труды Института истории материальной культуры РАН № ХХІІІ. СПб., 2007. 388 с.

5. Поплевко Г.Н. Первые данные трасологического исследования материалов Оленеостровской мезолитической стоянки (Южный Олений остров 1) // Записки Института истории материальной культуры РАН. Вып. 4. СПб., 2009. С. 63-76.

6. Поплевко Г.Н. Результаты трасологического исследования материалов неолитической стоянки Старые Войковичи 1 // Na rubieży kultur. Badania nad okresem neolitu i wczesną epoką brązu. Białystok, 20011. C. 305-320.

7. Поплевко Г.Н. Данные трасологического исследования материалов мезолитической стоянки Южный Олений остров 2 // Мезолит и неолит Восточной Европы: хронология и культурное взаимодействие. СПб., 2012. С. 50-53, 326-336.

8. Разлуцкая А.А. Отчет о полевых исследованиях на территории Барановичского района Брестской области в 2004 г. - Архив Институт истории Национальной Академии Наук Белоруссии, дело № 2183.

9. Разлуцкая А.А. Отчет о полевых исследованиях на территории Барановичского района в 2005 г. - Архив Самарский научный вестник. 2014. № 3(8) 
Институт истории Национальной Академии Наук з вярхоуяу Шчары у Заходняй Беларусі // Badania archeБелоруссии, дело № 2267.

10. Разлуцкая А.А. Раскопки торфяниковой стоянки Войковичи-1 на Колдычевском озере // Гістарычнаархеалагічны зборнік № 20. Мінск, 2005. С. 258-260.

11. Чернявский М.M. Новыя неалітычныя матэрыялы № 13-21-01003a/м ologiezne w Polsce pyinocno-wschodniej I na zachodniej Biaiorusi w Iatach 2000-2001. Białystok, 2002. C. 91-99.

Работа выполнена при поддержке РГНФ, проект

\section{PLANIGRAFICHESKY ANALYSIS MATERIAL SITE OLD VOYKOVICHI 1 (ACCORDING TRASOLOGY)}

(C) 2014

G.N. Poplevko, senior researcher experimental and trasological laboratory Institute of History of Material Culture of the RAS, St. Petersburg (Russia)

Annotation: A comprehensive study of flint materials peat site Old Voykovichi 1 includes technological, trasological and planigrafy analysis of flint. For the study were selected trasological all products retouched typologically decorated tools, plates and fragments thereof. The ratio between these typological and trasological analysis shows that using trasology we can get almost five times more guns and more complete picture of economic activity in the parking lot. On the excavation plan 2004-2005, all guns were applied separated by the trasological analysis. The basic amount of guns concentrated in the excavation in 2004 in several squares, arranged in an elongated spots. This suggested that this place was inhabited space site. Two more spots guns concentrations may be associated with production sites in the plaza parking lot. Thus, we can say that the study materials trasological archaeological monuments of the Stone Age enable us to refine the chronological past affiliation to recruit economic complex and to determine the type of hardware and guess the location of the monument of the living space. Site Old Voykovichi 1 can be defined as a seasonal hunting camp the final transition to the Mesolithic and Early Neolithic.

Keywords: Archaeology; Neolithic; comprehensive study; trasological analysis; reconstruction and economic activity; flint industry.

УДК 902

(C) 2014

\section{РАННИЙ НЕОЛИТ ВЕРХНЕГО ДОНА}

\section{P.B. Смольянинов, кандидат исторических наук, специалист}

ЛГОО «Археолог», Липеикк (Россия)

A.B. Сурков, кандидат исторических наук, ведущий консультант

Департамент культуры и архивного дела Воронежской области, Воронеж (Россия)

Аннотация: Традиционно ранний неолит Верхнего Дона ассоциировался с ранненеолитической среднедонской культурой, но исследования последних лет стоянок Карамышево 5, 9, Васильевский кордон 5, 7, Ивница и др. дали основания рассматривать начало неолита Верхнего Дона в рамках карамышевской культуры. Для датировки её имеется серия дат от начала V тыс. до н.э. до первой половины IV тыс. до н.э. (некалиброванные значения).

Ключевые слова: ранний неолит, керамика, карамышевская культура, Верхний Дон, накол, гребёнка.

На сегодняшний день в бассейне Верхнего Дона исследовано стационарно более 20 неолитических памятников, материалы которых позволили выделить рыбноозерскую и рязанско-долговскую (В.П. Левенок), среднедонскую (А.Т. Синюк) и карамышевскую культуры (Р.В. Смольянинов).

Традиционно ранний неолит региона ассоциировался со среднедонской культурой [1], но исследования последних лет стоянок Карамышево 5, 9, Васильевский кордон 5, 7, Ивница и др. дали основания рассматривать начало неолита Верхнего Дона в рамках карамышевской культуры.

Помимо названных древностей, Р.В. Смольяниновым в диссертационном исследовании в раннем неолите Верхнего Дона выделена керамика елшанской, верхневолжской и днепро-донецкой культур [2]. Но малочисленность этих материалов на сегодняшний день не позволяет в полной мере рассматривать их как критерий для выделения раннего неолита в регионе.

Отдельным вопросом остается ранненеолитический возраст памятников среднедонской культуры на Верхнем Дону - данных об их стратиграфическом предшествии или абсолютных датировок не имеется, в связи с чем эти материалы, вероятнее всего, необходимо рассматривать в рамках уже развитого этапа неолита.

Карамышевская культура нам известна по 26 памятникам (рис. 1), локализованным в бассейне р. Воронеж. Она имеет все основания для включения её в круг ранненеолитических древностей, поскольку имеются четкие стратиграфические данные, радиоуглеродные даты, да и эта хронологическая позиция соотносится с данны- ми по елшанской (особенно в свете новых исследований в Среднем Посурье), верхневолжской и другим ранненеолитическим культурам.

Необходимо сразу обратить внимание на прикладной характер используемого термина «культура» применительно к рассматриваемым материалам: в данном случае это совокупность признаков изготовления и декорирования керамической посуды, имеющая локализацию на местности и определенный хронологический диапазон при малом количестве каменного инвентаря в культурных слоях памятников. Выделение таких «культур» преследует цель обобщения имеющихся сведений с целью их анализа на фоне развития синхронных древностей сопредельных территорий.

Территориально выделяется несколько скоплений стоянок карамышевской культуры:

- в верхнем течении р. Воронеж у с. Преображеновка и посёлка Доброе Добровского района Липецкой области в правобережной пойме реки на останцах надпойменной террасы и береговых валах (Васильевский Кордон 5, 7, 25, Ратчино 22, Доброе 1, Студеновка 3);

- в среднем течении реки в окрестностях г. Липецка и у с. Карамышево Грязинского района Липецкой области в пойме на останцах надпойменной террасы (Липецкое Озеро, Шлюз, Гудовский Кордон, Красный Бугор, Карамышево 1, 5, 9, 19 и др.);

- в нижнем течении реки на границе Липецкой и Воронежской областей в пойме левого берега p. Воронеж на останцах надпойменной террасы (Савицкое 1, Курино 1, Ивница, Ступино). 